\title{
Good practices in agricultural production for environmental conservation and "climate change mitigation" in the Ciénega region of the Jalisco State
}

\section{Buenas prácticas de producción agrícola para la conservación del medio ambiente y "mitigación del cambio climático" en la región de la Ciénega del Estado de Jalisco}

\author{
LOZA-LLAMAS, Juana America ${ }^{1} \dagger^{*}$, FRÍAS-UREÑA, Héctor Gerardo ${ }^{1}$, MÉNDEZ-MORÁN, Lucila ${ }^{2}$ \\ and ROMO-REYES, María Magdalena ${ }^{1}$
}

${ }^{1}$ Departamento de Ciencias Ambientales, ${ }^{2}$ Departamento de Ecología, ${ }^{1,2}$ Centro Universitario de Ciencias Biológicas y Agropecuarias. Camino Ramón Padilla Sánchez No. 2100 Nextipac, Zapopan, Jalisco

ID $1^{\text {st }}$ Author: Juana America, Loza-Llamas / ORC ID: 0000-0003-1135-0754, Researcher ID Thomson: U-1402-2018, CVU CONACYT ID: 924239)

ID $1^{\text {st }}$ Coauthor: Héctor Gerardo, Frías-Ureña / ORC ID: 0000-0002-01784308, Researcher ID Thomson: X-3550-2019, CVU CONACYT ID: 175277 ID $2^{\text {nd }}$ Coauthor: Lucila, Méndez-Morán / ORC ID: 0000-0003-4733-6153, Researcher ID Thomson: U-1401-2018, Open
ID: 8418136100, CVU CONACYT ID: 121862

ID $3^{\text {rd }}$ Coauthor: María Magdalena, Romo-Reyes / ORC ID: 0000-0003-1234-0021, Researcher ID Thomson: U-14552018, CVU CONACYT ID: 950190

DOI: 10.35429/JURRE.2019.4.3.1.6

Received March 11, 2019; Accepted June 30, 2019

\section{Resumen}

La crisis ambiental que sufre el planeta es originada por múltiples factores, naturales y antropogénicos. En el sector agropecuario se desarrollan actividades que afectan directamente a los recursos naturales. Motivado por esa situación, se realizó el presente trabajo con el objetivo de identificar y promover el uso de buenas prácticas de producción agrícola para la conservación del medio ambiente y mitigación del cambio climático" en la región de la Ciénega del Estado de Jalisco. El trabajo se llevó a cabo en el "Rancho Experimental" propiedad de la Universidad de Guadalajara, ubicado en la localidad de San José Casas Caídas en el Municipio de La Barca, Jalisco. En el trabajo se contó con la participación de 23 productores agrícolas de los municipios de Ocotlán, La Barca y Jamay, del Estado de Jalisco. Un taller participativo fue realizado como estrategia metodológica, donde participaron diferentes actores de la actividad agropecuaria. Como parte de los resultados se identificaron los siguientes problemas: falta de agua, plagas y enfermedades, granizadas, presencia de malezas, ineficiente comercialización, así como la falta de financiamiento. Proponen implementar estrategias de conservación de suelos como; incorporación de residuos de la cosecha, rotación de cultivos, nivelación de suelos, aplicación de compostas, entre otros.

Taller participativo, Buenas prácticas, Conservación del suelo

\begin{abstract}
The environmental crisis suffered by the planet is caused by multiple factors, such as the natural and anthropogenic. In agropecuary sector, some activities are developing that directly affect the natural resources. Motivated by that situation, this work was carried out with the objective of identifying and promoting the use of good practices in agricultural production for environmental conservation and "climate change mitigation" in the Ciénega region of the State of Jalisco. The work was carried out in an "Experimental Ranch" of the University of Guadalajara, located in the town of San José Casas Caidas in the Municipality of La Barca, Jalisco. The work included 23 agricultural producers from the municipalities of Ocotlán, La Barca and Jamay, from the Jalisco state. A participatory workshop was held as a methodological strategy, where different actors of the farming activity participated. As part of the results, the following problems were identified: lack of water, pests and diseases, hailstorms, presence of weeds, inefficient commercialization, as well as lack of financing. They propose to implement of soil conservation strategies such as; incorporation of crop residues, crop rotation, soil leveling, application of composts, among others.
\end{abstract}

Participatory workshop, Good practics, Soil conservation

Citation: LOZA-LLAMAS, Juana America, FRÍAS-UREÑA, Héctor Gerardo, MÉNDEZ-MORÁN, Lucila and ROMOREYES, María Magdalena. Good practices in agricultural production for environmental conservation and "climate change mitigation" in the Ciénega region of the Jalisco State. Journal-Urban-Rural and Regional Economy. 2019. 3-4: 1-6

$\dagger$ Researcher contributing as first author. 


\section{Introduction}

Small and large agricultural producers use various productive techniques in their daily practice with the purpose of obtaining efficient results that are reflected in high levels of production yield and product quality. However, when defining the techniques to be used, when the relationship between their agricultural activity and the environment is not taken into account, practices that cause serious damage to natural resources with significant environmental effects are implemented.

Soil is one of the resources that suffers the effects of these practices, according to the information that Bai et. in 2013, 24\% of the world's soils show varying degrees of degradation, of which almost half are agricultural soils. In the report presented by FAO (2016), four strategies are proposed to increase food production by minimizing the negative environmental impact.

As a first strategy it is proposed to avoid the loss of productivity due to the degradation of the soil, the second is the closing of the yield gap, which consists in the difference between the yield of the crops observed in one place and the potential yield of the crop in the same place, if best practices and agricultural technologies are applied, the third is to ensure that land use maintains or expands carbon storage in the soil and in biodiversity, by promoting agricultural practices and sustainable land management, and the fourth strategy proposes to increase the efficiency of the use of agricultural inputs such as irrigation, fertilizers and pesticides.

Given this scenario, it is a priority that producers be trained to acquire the necessary tools that not only allow them to improve the yield and / or quality of their production, but that their practice does not cause damage to the environment and contribute to the conservation and mitigation of climate change.

A suitable training model for groups with the characteristics of agricultural producers, as well as obtaining information that serves as a diagnosis of the problem and proposals for improvement, are participatory workshops. Action that involves participants in the development of diagnoses, programs and / or work plans, where together they work to solve common problems (Geilfus, 2002).
This document presents the experience of the work carried out through the participatory Workshop "Use of good agricultural production practices for environmental conservation and climate change mitigation" that was carried out in the Ciénega region of the State of Jalisco, in the municipalities of Ocotlán, La Barca and Jamay.

\section{Objectives}

\section{Overall objective}

Identify and promote the use of good agricultural production practices for environmental conservation and climate change mitigation "in the Ciénega region of the State of Jalisco.

\section{Specific objectives}

1. Identify the conservation and soil management practices carried out by the various actors (agricultural producers, livestock and extension agents) in their activities

2. Know and prioritize the problems faced by producers in the development of their productive practices

3. Strengthen producers' knowledge about the value and importance of the resources that sustain all agricultural activities in the region, in addition to obtaining quick information on natural resources.

4. Feedback on the use of good agricultural production practices for environmental conservation and climate change mitigation

\section{Materials and methods}

The work was carried out in the "Experimental Ranch" owned by the University of Guadalajara, located in the town of San José Casas Caidas in the Municipality of La Barca, Jalisco.

There were 23 participants, agricultural producers, from the towns of Ocotlán, Loreto, Jamay, Teocuitatlán and La Barca, of which 19 cultivate corn and the rest sorghum, safflower, wheat, oats and soy. Supported by the Ministry of Rural Development (SEDER) of the State of Jalisco. 
As a methodological strategy for obtaining the results, a participatory workshop was held, entitled "Use of good agricultural production practices for environmental conservation and climate change mitigation" using the methodology of the 80 tools for participatory development de Geilfus (2002), and the guide for facilitators of participatory workshops of the American Agency for International Development (USAID), 2002.

Prior to the workshop, work meetings were held with technicians and officials of the SEDER, in order to agree on the descriptive letter, which includes for each of the 11 scheduled activities: allotted time, topics with their objectives, methodology, the products and responsible. The technicians who participated were those directly involved in the study regions, responsible for convening the different actors in the agricultural sector, as well as participating in the work tables making proposals to enrich the results.

The participatory workshop was developed in three stages: introduction, training and diagnosis of natural resources, as well as feedback to the project "Evaluation of carbon enrichment in the soil of four regions of Jalisco", through the visit to the experimental plots.

\section{Stage 1. Introduction:}

At this stage the attendees were registered, the objectives and program of the workshop were presented, in addition to the presentation of the attendees, for this point the dynamic called "Icebreaker" was carried out, so that the participants were known, in where each one presented himself and made a reflection on what he expected at the end of the workshop.

Stage 2. Training and diagnosis on natural resources:

Different techniques were developed to meet the objectives set at this stage. The "brainstorming" dynamic was applied, in order to obtain pertinent and rapid information from the participants on the identification of the natural resources that support the agricultural activity of the region.
The same dynamic was used to identify and describe the practices of conservation and soil management, through a base of questions about who uses the different practices? How do they do it? and why do they do it? The different practices identified classified them in terms of their economic, environmental and social sustainability.

In order to know and prioritize the problems that producers face in the development of their productive practices, this activity was carried out with the support of the double entry identification matrix with the same number of lines and columns as there are problems identified, prioritizing problems.

Stage 3. Feedback to the project through the visit to the experimental plots

The participants were transferred to the experimental area in order to know the effect of the application of various doses of compost in the crops, they were explained that they had six treatments (control, 5, 10, 15 and 20 tons of compost per hectare, as well as 10 tons per hectare of vermiabono) with three repetitions each. Signaling was placed on each of the treatments. They were given a questionnaire to carry out the evaluation of agronomic characteristics of corn cultivation by treatment, where they indicated which was the best and worst. The agronomic characteristics that were taken into account in order to define the best or worst treatments were: height, color, health vigor (disease), acame, number of ears greater than $20 \mathrm{~cm}$., Percentage of filling of the cob, as well as the yield Estimated by treatment. In addition, they were asked if they found differences between treatments and why?

\section{Results}

The participatory workshop was held at the "Experimental Ranch" owned by the University of Guadalajara, located in the town of San José Casas Caidas in the Municipality of La Barca, Jalisco.

23 producers participated, from the towns of Ocotlán, Loreto, Jamay, Teocuitatlán and La Barca, grow corn, sorghum, safflower, wheat, oats and soy. 
The dynamic that was developed to promote communication among the attendees was effective, because it facilitated the fulfillment of the established objectives, building an atmosphere of trust and cordiality that helped propose ideas in a group.

The recognition of the natural resources that the region has was the first diagnosis that was made with the assistants, through the question, What are the natural resources that the region has and that are important for agricultural activity? The answer was that there are eight natural resources, which are important to develop their activities, giving priority to water, soil and air. The information collected was reclassified and by the number of mentions, they were grouped into: climate, in which they included temperature, air and temporary first, continuing with the soil and water, and also identifying the flora (vegetation and improved seeds ) and fauna (microorganisms), as well as involving the sun. Table 1 lists the natural resources and the number of times they were mentioned as priorities.

\begin{tabular}{|l|l|}
\hline \multicolumn{1}{|c|}{ Resource } & $\begin{array}{r}\text { Number of } \\
\text { mentions }\end{array}$ \\
\hline SUN & 1 \\
\hline SOIL (organic matter, minerals) & 7 \\
\hline $\begin{array}{l}\text { CLIMATE (temperature, air, } \\
\text { precipitation) }\end{array}$ & 12 \\
\hline FAUNA (microorganisms) & 2 \\
\hline FLORA (vegetation, improved seeds) & 2 \\
\hline WATER (temporary) & 3 \\
\hline
\end{tabular}

Table 1 Perception of the environment and natural resources of the region

Through plenary presentations, the threedimensional value of the soil and its interactions, as well as the convenience of enriching the organic matter of the soil, the role of the seeds in the production process, and allowing interaction with Attendees were allowed to extend the information according to the needs regarding the doubts that the participants had.

After reaffirming the importance of the soil as a natural resource that is a priority for the realization of its activities, it was important to know the different activities carried out in the region of La Barca, on the management and conservation of the soil, the actions they perform and how They do them. The results can be seen in table 2 .

\begin{tabular}{|l|l|}
\multicolumn{1}{c}{$\begin{array}{c}\text { Different } \begin{array}{c}\text { How do they do that? } \\
\text { conservation practices }\end{array} \\
\text { Compost Application }\end{array}$} & Using bovine excreta \\
\hline $\begin{array}{l}\text { Application of mineral } \\
\text { broths }\end{array}$ & $\begin{array}{l}\text { Developing cooking and } \\
\text { fermentation processes, in } \\
\text { addition to the application of } \\
\text { nitrogen in a liquid way }\end{array}$ \\
\hline $\begin{array}{l}\text { Conservation } \\
\text { agriculture }\end{array}$ & $\begin{array}{l}\text { Carrying out direct sowing } \\
\text { with precision sowing, } \\
\text { incorporation of organic } \\
\text { matter (crop remains) is } \\
\text { done with a tractor, zero } \\
\text { tillage }\end{array}$ \\
\hline Ground leveling & $\begin{array}{l}\text { According to the slope with } \\
\text { laser beams }\end{array}$ \\
\hline $\begin{array}{l}\text { Incorporation } \\
\text { beneficial } \\
\text { microorganisms }\end{array}$ & $\begin{array}{l}\text { It is done to the ground } \\
\text { manually or machinery, }\end{array}$ \\
\hline Parcel drain & $\begin{array}{l}\text { Mechanical or manual form, } \\
\text { ditches }\end{array}$ \\
\hline $\begin{array}{l}\text { Seed inoculation with } \\
\text { microorganisms }\end{array}$ & $\begin{array}{l}\text { The seed is prepared with } \\
\text { microorganisms (fungi and } \\
\text { bacteria). Silicon, sugar and } \\
\text { water are added as adherent. }\end{array}$ \\
\hline Soil analysis & $\begin{array}{l}\text { They take 5 samples per } \\
\text { hectare, mix and obtain a } \\
\text { sample for delivery to the } \\
\text { laboratory and perform the } \\
\text { analysis. }\end{array}$ \\
\hline
\end{tabular}

Table 2 Soil management and conservation practice

The various actors prioritize the activities of Conservation Agriculture, such as direct sowing, minimum tillage and the incorporation of crop residues, as well as the leveling of soils, drainage of the plots, in addition to the incorporation of beneficial microorganisms.

Once they analyzed the natural resources that the region has, as well as the soil management and conservation practices they perform, it was important to know and prioritize the problems that producers face in the development of their productive practices. The actors were grouped according to the region and formed three groups: Teocuitatlán de Corona and Jamay, the second those of Loreto and La Barca, and the third those that came from Ocotlán. For the first group, the main problems they face are temporary, lack of regional programs, as well as lack of very expensive bank credits or credits. The producers of La Barca and Loreto, for their part, mentioned that the three main problems of the eight they detected are: lack of water, pests and diseases, as well as the presence of weather events such as hailstorms. 
On the other hand, the presence of weeds, poor marketing and lack of financing were three of the main problems mentioned of the eight that they detected.

In addition to the previous activities, the attendees were informed about the project that is being developed for the second consecutive year, highlighting the methodology and results of the 2017 productive cycle. Subsequently, they were invited to visit the experimental plots, in order to carry out the evaluation of the phenological development of corn with the different doses of organic fertilizer used, as well as the performance of the various treatments. It is worth mentioning that the experimental plots presented signage in order to facilitate the activity. The evaluation results are described below.:

The assistants described that the plants that presented greater height were those of the treatment that contains 10 ton of vermiabono per hectare, followed by the plot of 15 tons of compost, the three groups agreed that those of less stature were the plants of the control treatment; in relation to color, they pointed out that the most vivid green could be observed in floods with vermiabono, contrary to those of the witness that showed a yellowish green; the plants considered with greater vigor were those grown with the treatment of 20 tons of compost, followed by the treatments with vermiabono and 15 tons of compost, the opposite were those of the control and 5 tons of compost;

As for the health of the plant, they described that those grown with the treatment of 20 tons of compost were the healthiest, followed by that of 10 of vermiabono that did not present diseases, on the contrary to the most damaged plants were those of the treatment witness; no treatment was presented at any time; the number of ears greater than $20 \mathrm{~cm}$ established it as present in those developed with vermiabono and with 20 tons of compost, being lower in the control; the filling of the cob is an important characteristic in the production, which the producers could validate, mentioning that those that were developed with vermiabono have 90 to $95 \%$, followed with $90 \%$ those present in the treatment of 20 tons of compost, contrary to the witness with only $70 \%$;
As for the projection of the production yield of ton per hectare, the best qualified was the treatment of 20 tons of compost with a prediction of 5.2 to 7.5 tons, followed by the enriched with vermiabono between 4.5 to 7.5 and the lowest yield was the witness with 3.2 to 4 tons.

Subsequently, producers and technicians were requested, based on their experience, to make feedback proposals to the project, in order to analyze and incorporate them into the project. The proposals they recommended are listed in the following table:

\begin{tabular}{|c|c|}
\hline & in time \\
\hline- & Sow in the furrow \\
\hline & $\begin{array}{l}\text { Execute drainage lines, in addition to the internal } \\
\text { drains of the plot }\end{array}$ \\
\hline & Pest t \\
\hline & The \\
\hline & $\begin{array}{l}\text { iderar a la materia orgánica como } \\
1 \text { suelo }\end{array}$ \\
\hline & $\begin{array}{l}\text { Incorporar } 2000 \text { kilos de composta al momento de } \\
\text { la siembra y } 150 \text { kilos de triple } 17 \\
\text { Agregar } 200 \text { kilos de urea por hectárea, } \\
\text { combinando como segunda fertilización }\end{array}$ \\
\hline & $\begin{array}{l}\text { Agregar lixiviado de lombriz, enriquecido con } \\
\text { micro elementos }\end{array}$ \\
\hline & $\begin{array}{l}\text { Realizar control biológico de plagas, colocando } \\
\text { trampas con feromonas (para controlar el adultos } \\
\text { del gusano cogollero), dos trampas por hectárea }\end{array}$ \\
\hline & $\begin{array}{l}\text { Agregar a la siembra } 200 \mathrm{~kg} \text { de silicio por hectárea, } \\
\text { mezclada con composta para control de insectos, } \\
\text { además le da estructura a la planta }\end{array}$ \\
\hline
\end{tabular}

Table 3 Feedback Proposals

Other information that was generated in the workshop, were the proposals of action that should be extended among agricultural producers in the region for soil conservation, indicating six main ones, which are listed in Table 4:

\begin{tabular}{|l|}
\hline 1. Incorporation into the soil of crop residues, shears \\
\hline $\begin{array}{l}\text { 2. Perform crop rotation (oats, chickpea, wheat, } \\
\text { sorghum, corn, safflower) }\end{array}$ \\
\hline 3. Perform soil leveling \\
\hline 4. Compost application (M.O.) \\
\hline 5. Apply beneficial microorganisms (Beauveria \\
bassiana is applied to the soil and the plant via foliar, \\
$250 \mathrm{~g}$ / $200 \mathrm{~L}$ per ha, you can increase the yield for 10 \\
ha, adding 10 kg of flour and 101 of molasses, you can \\
apply up to on three occasions with intervals of 15 days, \\
with winds less than 10 kilometers per hour, with a type \\
3 nozzle. Controls buds, mites, suckers, white mosquito \\
\hline 6. Minimum tillage or zero tillage systems. \\
\hline
\end{tabular}

Table 4 Proposals for soil management and conservation in agricultural production in the region 


\section{Conclusions}

The natural resources that are present in the region and that are important to develop their agricultural activities are: the climate, in which they included temperature, air and temporary first, continuing with the soil and water, the flora (vegetation and improved seeds) and fauna (microorganisms), as well as the sun.

The various actors prioritize the activities of Conservation Agriculture, such as direct sowing, minimum tillage and the incorporation of crop residues, as well as the leveling of soils, drainage of the plots, in addition to the incorporation of beneficial microorganisms.

The main problems that producers face in the development of their productive practices have been: for Teocuitatlán de Corona and Jamay, they are temporary, lack of regional programs, as well as lack of very expensive bank credits or credits; Loreto and La Barca producers, for their part, mentioned that the three main problems of the eight they detected were: lack of water, pests and diseases, as well as the presence of weather events such as hailstorms; The Ocotlán group have faced the presence of weeds, inefficient commercialization, as well as lack of financing.

The main proposals for feedback to the project were: schedule the planting taking into account the storm, sow in time; sow in the furrow; run drain lines, in addition to the internal drains of the plot; pest trapping; land leveling to avoid flooding and perform biological control of pests.

The proposed actions that should be extended among agricultural producers in the region for soil conservation were: implement minimum tillage or zero tillage systems, such as the incorporation of crop residues and shears into the soil, in addition to the application of composts; perform crop rotation (oats, chickpea, wheat, sorghum, corn, safflower); level the floors; apply beneficial microorganisms (Beauveria bassiana) to the soil and to the plant via foliar.
The capacity of observation of the producers and the empirical knowledge that they develop is very wide, and although they do not perceive the soil as a three-dimensional element, if they perceive it as a finite resource that must be conserved for the sustainability of their activities.

\section{References}

Agencia Estadounidense para el Desarrollo Internacional (USAID), (2002). Una guía para facilitadores de talleres participativos que

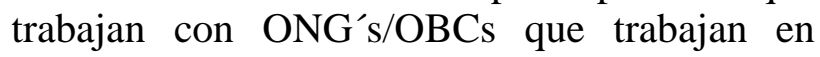
VIH/Sida. Queensbery Hou Internacional HIV/AIDS Alliance. al HIV/AIDS Alliance.

Bai, J., Xiao, R., Zhang, K., Gao, H., Cui, B., \& Liu, X. (2013). Soil organic carbon as affected by land use in young and old reclaimed regions of a coastal estuary wetland, China. Soil Use and Management, 29(1), 57-64.

FAO (2016). Estado Mundial del Recurso Suelo, informe 2015. Resumen Técnico. http://www.fao.org/3/a-i5126s.pdf

Geilfus, Frans (2002). 80 herramientas para el desarrollo participativo: diagnóstico, planificación, monitoreo, evaluación - San José, C.R.: IICA,. 217 